\title{
IMPLEMENTASI PEMBELAJARAN BERBASIS KARAKTER PADA MATA PELAJARAN BAHASA INDONESIA SISWA KELAS VIII SMP NEGERI SATU ATAP 1 MAROBO KABUPATEN MUNA
}

\author{
Nia Asriana Hasini ${ }^{1}$, Sahlan $^{2}$, Aris Badara ${ }^{3}$ \\ 1,2,3 Universitas Halu Oleo \\ Email: niaasriana.hasini@yahoo.com ${ }^{1}$, alansahlan17@yahoo.com² \\ arisbadara71@yahoo.co.id ${ }^{3}$
}

\begin{abstract}
Abstrak: Penelitian ini bertujuan untuk; (1) menganalisis dan mendeskripsikan implementasi pembelajaran Berbasis karakter pada mata pelajaran Bahasa Indonesia siswa kelas VIII SMP Negeri Satu Atap 1 Marobo Kab. Muna; (2) faktor penghambat dalam penerapan pembelajaran berbasis karakter pada mata pelajaran Bahasa Indonesia siswa kelas VIII SMP Negeri Satu Atap 1 Marobo Kab. Muna; (3) faktor pendukung dalam penerapan pembelajaran berbasis karakter pada mata pelajaran Bahasa Indonesia siswa kelas VIII SMP Negeri Satu Atap 1 Marobo Kab. Muna. Penelitian ini merupakan penelitian kualitatif. Hasil analisis disimpulkan (1) Implementasi pembelajaran berbasis karakter pada mata pelajaran Bahsa Indonesia pada siswa kelas VIII SMP Negeri Satu Atap 1 Marobo sudah diterapkan, terbukti dari hasil analisis (APKG1) yang terdiri dari perencanaan pembelajaran guru, dan (APKG2) yang terdiri dari pelaksaan pembelajaran dan evaluasi pembelajaran guru. Namun pelaksanaanya belum sepenuhnya ditanamkan, seperti: 1) guru tidak tepat waktu, 2) guru hanya menggunakan media sendiri, (2) faktor penghambat dilihat dari beberapa faktor yaitu: faktor luar terdiri dari faktor lingkungan dan pemerintah, sedangkan pada faktor dalam yaitu mental, kesadaran, motivasi dan disiplin. (3) faktor pendukung dilihat dari beberapa faktor yaitu: faktor internal dapat dilihat dari fisiologis siswa, sedangkan pada faktor eksternal dapat dilihat dari lingkungan non sosial.
\end{abstract}

Kata Kunci: Implementasi; Pembelajaran Bahasa Indonesia; Pendidikan Karakter 


\section{Pendahuluan}

Remaja merupakan suatu fase transisi dari masa awal anak-anak hingga masa awal dewasa. Pada umumnya ditandai dengan perubahan pada fisik mereka, tidak hanya itu saja sebenarnya kondisi psikologi mereka juga mengalami perubahan terutama dalam pola pikir setiap individunya. Pada situasi ini remaja juga akan mengalami berbagai goncangan yang semakin mempengaruhi psiokolgi mereka, dan tidak banyak dari mereka yang tidak kuat akan terjerumus pada halhal yang kurang baik. Dalam fase ini pula remaja mulai mencari jati diri mereka atau karakter mereka sendiri. Salah satu tugas remaja dalam perkembanganya yaitu untuk mencari identitas diri agar nanti nya remaja dapat menjadi orang dewasa yang unik dengan sense of self yang koheren dan peran yang bernilai di masyarakat. Tapi pada dasarnya pernyataan tersebut tidaklah sama dengan kenyataannya dan bahkan berbanding terbalik dengan fakta yang ada di Indonesia sekarang ini, tidak banyak dari remaja kini yang belum mengetahui jati diri mereka atau karakter mereka masing masing. Bahkan tidak jarang banyak remaja yang masih terjebak dalam krisis karakter, maka dari itu perlu adanya pendidikan karakter dalam penanganannya.

Berbicara tentang karakter berarti membahas tentang kepribadian atau akhlak. Kepribadian merupakan ciri, karakteristik, atau sifat khas diri seseorang yang membedakanya dengan orang lain. Karakteristik seseorang biasa terbentuk dari lingkungan (keluarga) dan bawaan sejak lahir. Dalam proses perkembangan dan pembentukannya, karakter seseorang dipengaruhi oleh dua faktor, yaitu faktor lingkungan (nurture) dan faktor bawaan (nature). Dimana sekarang ini terkadang peran keluarga dalam pembentukan karakter pada anak lebih sedikit dibandingkan peran lingkungan disekelilingnya, hal tersebut biasa disebabkan oleh faktor kesibukan orang tua dan menganggap anaknya baik-baik saja tanpa masalah, pemikiran orang tua yang menggangap anaknya baik-baik saja merupakan hal yang fatal, seorang anak yang sedang memasuki fase remaja membutuhkan bimbingan orang tua yang bisa dijadikan sebagai teman, kakak, ayah, ibu agar bisa mengeluarkan apa yang ada didalam fikiranya. Seorang remaja yang kurang mendapatkan perhatian dari keluarganya biasa melakukan perbuatan yang mengundang banyak perhatian agar diperhatikan sehingga mengakibatkan kencenderungan anak untuk berbuat negatif seperti menggunakan miras, alkohol, serta belum lama ini sering terjadi pelecehan sexual yang dilakukan remaja, maka dari itu perlu adanya suatu pendidikan karakter dilingkungan sekolah yang diantaranya sangat berperan penting dalam pembetukan karakter peserta didiknya. Dari berbagai peristiwa diatas dan yang terjadi saat ini jelas menunjukkan penyimpangan pendidikan karakter pada anak maupun remaja. Tata krama, etika siswa saat ini disinyalir kian menyimpang akibat melemahnya pendidikan karakter bangsa.

Salah satu alternatif dalam mengatasi hal tersebut adalah melalui pendidikan karakter terpadu, yaitu memadukan dan mengoptimalkan kegiatan pendidikan informal lingkungan keluarga dengan pendidikan formal di sekolah. Pembentukan karakter merupakan bagian dari pendidikan nilai (values education), melalui sekolah merupakan usaha mulia yang mendesak untuk dilakukan. Bahkan, kalau kita berbicara tentang masa depan, sekolah bertanggungjawab bukan hanya dalam 
mencetak peserta didik yang unggul dalam ilmu pengetahuan dan teknologi, tetapi juga dalam jati diri, karakter dan kepribadian.

Menurut (Badara, dkk 2018) "it is expected that school can be an effective medium of transforming cultural values that are the pillars of national cultures as a means of national unity". "diharapkan sekolah dapat menjadi media yang efektif mengubah nilai budaya yang menjadi pilar budaya nasional sebagai sarana Nasional Kesatuan". Dalam hal ini, waktu belajar peserta didik di sekolah perlu dioptimalkan agar meningkatan mutu hasil belajar, terutama pembentukan karakter peserta didik.

Pendidikan karakter dapat diintegrasikan dalam pembelajaran pada setiap mata pelajaran, tidak terkecuali pelajaran Bahasa Indonesia di Sekolah Menengah Pertama yang materi pembelajaranya berkaitan dengan norma atau nilai-nilai yang perlu dikembangkan, dieksplisitkan, dikaitkan dengan konteks kehidupan sehari-hari, sehingga penting dikaji tentang implementasi pelajaran Bahasa Indonesia berbasis karakter. Hal ini dilakukan untuk melihat seberapa besar penerapan nilai-nilai karakter yang diterapkan guru di dalam pelajaran Bahasa Indonesia.

Penelitian relevan yang pernah dilakukan oleh Miftahul Arifin (2013) didapatkan hasil implementasi pembelajaran karakter pada pembelajaran Bahasa Indonesia dapat terlaksana dengan baik dan secara garis besar yaitu dengan adanya tindakan seperti: perencanaan pembelajaran, pelaksanaan pembelajaran, dan evaluasi pembelajaran. Sehubungan dengan penelitian tersebut peneliti tertarik untuk melakukan penelitian yang berkaitan dengan pendidikan karakter pada mata pelajaran Bahasa Indonesia.
Hasil observasi awal yang dilakukan oleh peneliti tanggal 13 Agustus 2019 di SMP Negeri Satu Atap 1 Marobo memiliki dokumen-dokumen tertulis yang berupa visi dan misi yang disusun menggambarkan nilai-nilai pendidikan karakter di dalamnya. Gurunya juga mengatakan bahawa secara umum ada 18 nilai-nilai pendidikan karakter dalam pembelajaran tetapi guru tersebut menerapkan nilai pembelajaran pendidikan karakter pada mata pelajaran Bahasa Indonesia hanya pada 5 nilai yaitu religius, disiplin, jujur, kerja keras dan peduli lingkungan.

Berdasarkan hal tersebut peneliti memilih SMP Negeri Satu Atap 1 Marobo sebagai objek yang akan diteliti, dan pemilihan kelas VIII dikarenakan kelas tersebut merupakan objek ideal untuk penerapan pendidikan karakter. Hal ini ditinjau dari usia mereka yang tergolong masih beranjak dewasa sehingga potensi untuk pengembanganya lebih cepat. Terutama dalam penerapan konsep pendidikan karakter.

\section{Hakikat Implementasi}

Dalam Kamus Besar Bahasa Indonesia pengertian implementasi adalah pelaksanaan atau penerapan. (Setiawan,2019, https://kbbi.web.id/implementasi).

Implementasi merupakan sesuatu yang bermuara pada aktivitas, aksi, tindakan atau juga aktivitas yang dilakukan dengan secara sistematis serta terikat oleh mekanisme. Karena begitu, implementasi tersebut bukan sekedar aktivitas, namun suatu kegiatan atau aktivitas yang terencana serta untuk mencapai tujuan kegiatan atau aktivitas,(Ibeng,2019, https://pendidikan.co.id/pengertianimplementasi-tujuan-contoh-dan-menurutpara-ahli/). Implementasi tidak dapat 
berdiri sendiri sehinggasangat dipengaruhi oleh objek berikutnya yaitu kurikulum.

Berdasarkan hal tersebut dapat disimpulkan bahwa implementasi adalah segala bentuk upaya yang dilakukan untuk menegakkan apa yang telah dirancang dan kemudian bisa dijalankan dengan sepenuhnya.

\section{Pengertian Pendidikan Karakter}

Secara filosofis, konsep pendidikan mempunyai arti yang sangat luas, yaitu mengandung makna bagaimana proses pendidikan itu dilakukan, dan apa yang menjadi tujuanya. Pendidikan sebagai proses berarti merupakan prosedur yang harus dilakukan oleh peserta didik dalam menjalankan aktivitas pendidikan agar dapat menghasilkan tujuan yang terbaik sesuai dengan yang direncanakan. Pendidikan sebagai tujuan yaitu menjadikan anak didik menjadi cerdas, mandiri, dan memiliki karakter yang kuat sesuai dengan falsafah idiologi suatu bangsa lebih lanjut, Dewantara (dalam Ningsih 2015:14) menjelaskan bahwa pendidikan adalah upaya untuk memajukan perkembangan budi pekerti (kekuatan batin), pikiran (intelektual), dan jasmani anak-anak. Pendidikan menurutnya adalah untuk memajukan kesempurnaan hidup, yakni kehidupan dan penghidupan anak yang selaras dengan alam dan masyarakat. Metode pengajaran dan pendidikan yang lebih cocok menurutnya adalah sistem among dengan pola asih, asah, dan asuh. Metode ini meliputi: kepala, hati, dan panca indra.

Pendidikan mempunyai arti yang sangat luas, salah satunya adalah suatu aktivitas atau upaya secara sadar yang dilakukan oleh pendidik kepada peserta didik terhadap semua aspek perkembangan kepribadian, baik jasmani, dan ruhani, secara formal, informal, dan non formal yang berjalan terus-menerus untuk mencapai kebahagiaan dan nilai yang tinggi (baik nilai insaniyah maupun ilahiyah). Sementara itu, karakter merupakan nilai-nilai perilaku manusia yang berhubungan dengan Tuhan Yang Maha Esa, diri sendiri, sesama manusia, lingkungan, dan kebangsaan yang terwujud dalam pikiran, sikap, perasaan perkataan dan perbuatan berdasarkan norma-norma agama, hukum, tata karma, budaya, dan adat istiadat. Salah satu cara untuk membangun karakter seseorang adalah melalui pendidikan. Pendidikan yang ada baik itu pendidikan yang ada dikeluarga, masyarakat, atau pendidikan formal disekolah harus menanamkan nilainilai untuk pembentukan karakter.

Pendidikan karakter perlu didekatkan sebagai bagian dari nilai dan budaya generasi muda Indonesia sehingga menjadi pola sikap dan kultur dalam membangun peradaban bangsa. Secara umum ada 18 nilai-nilai pendidikan karakter dalam pembelajaran, Sahlan dkk (2014: 39) namun nilai pendidikan karakter secara keseluruhan belum diterapkan secara optimal di SMP Negeri Satu Atap 1 Marobo Kab.Muna.

\section{Pembangunan Pendidikan Karakter}

Faridah (2012: 92) mengatakan bahwa salah satu upaya pemerintah dalam pembangunan pendidikan karakter adalah menjadikan pendidikan karakter salah satu program prioritas pembangunan nasional. Kebijakan pembangunan karakter secara implinsit ditegaskan dalam Rencana Pembangunan Jangka Panjang Nasional (RPJPN) tahun 2000-2005, di mana pendidikan karakter ditempatkan sebagai landasan untuk mewujudkan visi pembangunan nasional, yaitu mewujudkan masyarakat berakhlak mulia, bermoral, beretika, berbudaya, dan beradab berdasarkan filsafah pancasila. 
Berdasarkan pendapat beberapa para ahli diatas dapat disimpulkan bahwa pembangunan pendidikan karakter dimulai dari lingkungan keluarga, satuan pendidikan, masyarakat sipil, masyarakat politik, pemerintah, dunia usaha, dan media massa.

Pembelajaran Berbasis Karakter di SMP Berdasarkan K13

Menurut Abidin (2018:23) dalam praktisnya kurikulum 2013 harus diimplementasikan melalui pembelajaran berbasis aktivitas yang berbasis pendekatan ilmiah dan tematik integratife. Hal ini senada dengan apa yang dinyatakan dalam Permendikbud Nomor 65 tentang Standar Proses bahwa untuk memperkuat pendekatan ilmiah (scientific), tematik terpadu (tematik antarmata pelajaran), dan tematik (dalam suatu mata pelajaran) perlu diterapkan pembelajaran berbasis penyingkapan/ penelitian (discovery/inquiry learning). Untuk mendorong kemampuan peserta didik untuk menghasilkan karya kontekstual, baik individual maupun kelompok sangat disarankan menggunakan pendekatan pembelajaran yang menghasilkan karya berbasis pemecah masalah (project based learning). Melalui pendekatan itu diharapkan siswa kita memiliki kompetensi sikap, keterampilan, dan pengetahuan, jauh lebih baik. Mereka akanlebih kreatif, inovatif, dan lebih produktif, sehingga nantinya mereka bisa sukses dalam menghadapi berbagai persoalan dan tantangan didalamnya, memastikan masa depan lebih baik.

Pembelajaran Berbasis Karakter Pada Pelajaran Bahasa Indonesia Di SMP

Aqib (2011: 53) integrasi pendidikan karakter dalam proses pembelajaran dilaksanakan mulai dari tahap perencanaan, pelaksanaan, sampai evaluasi pembelajaran pada semua mata pelajaran. Di antara prinsip-prinsip yang dapat diadopsi dalam membuat perencanaan pembelajaran (merancang kegiatan pembelajaran dan penilaian dalam silabus, RPP, dan bahan ajar), melaksanakan proses pembelajaran, dan evaluasi adalah prinsip-prinsip pembelajaran kontekstual (Contextual Teaching and Learning) yang selama ini telah diperkenalkan kepada guru seluruh Indonesia sejak 2002.

\section{Faktor Pendukung dan Penghambat dalam Pelajaran Bahasa Indonesia Berbasis Karakter Di SMP}

\section{Faktor Pendukung Penerapan Pendidikan Karakter}

Menurut Muthohar (2015: 37) terdapat banyak faktor yang mempengaruhi terbentuknya sebuah karakter.Dari sekian banyak faktor tersebut, dapat digolongkan kedalam dua bagian yaitu faktor intern dan faktor ekstern.

\section{Faktor Intern}

Faktor internal merupakan faktor yang berasal dari dalam diri individu dan dapat mempengaruhi hasil belajar individu.

\section{Faktor Ekstern}

Selain faktor intern (yang bersifat dari dalam) yang dapat mempengaruhi karakter, juga terdapat faktor ekstern (yang bersifat dari luar)

\section{Faktor Penghambat Penerapan Pendidikan Karakter}

Menurut Ardan (2017: 23) faktor penghambat dalam penerapan pendidikan karakter disebabkan memudarnya nilainilai karakter dalam kehidupan berbangsa dan bernegara. Nilai-nilai karakter itu menjadi pudar karena kurangnya perhatian dari keempat olah yang menjadi pilar 
utama mengembangkan pendidikan karakter yang kemudian termanifestasinya bias beragam dalam berbagai konteks politik, sosial, ekonomi, dan budaya.

Dari beberapa pendapat para ahli di atas dapat disimpulkan faktor penghambat dalam pendidikan karakter terdiri atas: (1) faktor luar seperti lingkungan (keadaan geografis), masyarakat luas, dan pemerintah. (2) faktor dalam seperti mental, kesadaran, motivasi, disiplin, dll.

\section{Pembelajaran Berbasis Karakter}

Pembelajaran berbasis karakter adalah suatu program pembelajaran yang dilakukan institut pendidikan yang bertujuan untuk membangun kesadaran terhadap pentingnya memahami, peduli, dan bertindak dengan mengedepankan nilai-nilai etika dan moral. Nilai-nilai karakter yang dimaksud seperti kejujuran, amanah, disiplin, cinta Tanah Air, dan berempati. Nilai-nilai ini jika diintegratisikan ke dalam pembelajaran, maka sebenarnya itulah yang disebut dengan pendidikan berbasis karakter. Artinya, nilai-nilai karakter dan budaya bangsa dikembangkan dan diintegratisikan pada aktivitas pembelajaran tanpa harus membahas satu demi satu nilai-nilai yang dimaksud secara terpisah. Nilai-nilai tersebut sudah diterapkan pada semua mata pelajaran tidak terkecuali mata pelajaran bahasa Indonesia di Sekolah Menengah Pertama.

Berdasarkan uraian di atas dapat di simpulkan bahwa pembelajaran berbasis karakter adalah pendidikan karakter yang diintegrasikan di dalam proses pembelajaran pengenalan nilai-nilai, fasilitas diperolehnya kesadaran akan pentingnya nilai-nilai, dan penginternalisasian nilai-nilai ke dalam tingkah laku peserta didik sehari-hari melalui proses pembelajaran, baik yang berlangsung di dalam kelas maupun yang di luar kelas pada mata pelajaran bahasa Indonesia.

\section{Model Pembelajaran}

Menurut Daryanto (2013:73) pendidikan merupakan salah satu strategi dasar dari pembangunan karakter bangsa yang dalam pelaksanaanya harus dilakukan secara koheren. Strategi pelaksanaan pendidikan karakter di satuan pendidikan merupakan suatu kesatuan dari program manajemen peningkatan mutu berbasis sekolah yang terimplementasi dalam pengembangan, pelaksanaan dan evaluasi kurikulum oleh setiap satuan pendidikan. Agar pendidikan karakter dapat dilaksanakan secara optimal, pendidikan karakter diimplementasikan melalui langkah-langkah berikut: a) Sosialisasi ke stakeholders (komite sekolah, masyarakat, lembaga-lembaga), b) Pengembangan dalam kegiatan sekolah.

\section{Model Pembelajaran Diskusi Kelas} Menurut Rohyanti (2015:19) metode pembelajaran diskusi adalah metode pembelajaran yang menghadapkan siswa pada suatu permasalah. Tujuan utama metode ini adalah untuk memecahkan suatu permasalah, menjawab pertanyaan, menambah dan memahami pengetahuan siswa, serta untuk membuat keputusan, karena itu diskusi bukanlah debat yang bersifat mengadu argumentasi. Diskusi lebih bersifat bertukar pengalaman untuk menentukan keputusan tertentu secara bersama-sama.

\section{Metode Penelitian}

Penelitian ini dilaksanakan di SMP Negeri Satu Atap 1 Marobo Kelas VIII pada semester ganjil tahun pelajaran 2018/2019 di Marobo Kabupaten Muna Provinsi Sulawesi Tenggara. Penelitian ini 
dilaksanakan selama tiga bulan, yaitu November 2019-Januari 2020. Jenis penelitian ini merupakan penelitian kualitatif, yaitu penelitian yang dilakukan dengan tujuan utama untuk menganalisis dan mendeskripsikan implementasi pembelajaran berbasis karakter pada mata pelajaran Bahasa Indonesia siswa kelas VIII SMP Negeri satu Atap 1 Marobo Kab. Muna.

Data pada penelitian ini adalah hasil analisis implementasi pembelajaran berbasis karakter pada mata pelajaran Bahasa Indonesia siswa kelas VIII SMP Negeri satu Atap 1 Marobo yang terdiri atas pembelajaran guru yang dimulai dari tahap perencanaan pembelajaran, pelaksanaan pembelajaran, dan evaluasi pembelajaran.

Sumber data yang dipergunakan dalam penelitian ini didasari data sumber informan yang terdiri terdiri dari 1 orang guru, yaitu guru Bahasa Indonesia yang mengajar di SMP Negeri Satu Atap 1 Marobo mulai dari tahun 2007, hingga saat ini masih berstatus sebagai guru Guru Tidak Tetap (GTT). Sumber data tertulis atau dokumen diperoleh dari guru mata pelajaran bahasa Indonesia kelas VIII, data tertulis tersebut diantaranya adalah RPP dan Silabus tahun pelajaran 2018-2019 yang memuat tentang materi pokok teks eksposisi dalam mata pelajaran Bahasa Indonesia.

Instrumen dalam penelitian sangatlah penting karena instrumen berfungsi sebagai alat bantu untuk mengumpulkan data yang diperlukan. Dalam penelitian ini, peneliti menggunakan instrumen Alat Penilaian Kemampuan Guru (APKG 1) untuk menganalisis tahap perencanaan pembelajaran yang terdiri dari RPP dan silabus guru, dan Alat Penilaian Kemampuan Guru (APKG 2) untuk menganalisis pelaksanaan pembelajaran, dan evaluasi pembelajaran guru. Selain itu instrument pendukung dalam penelitian ini adalah pedoman wawancara, observasi dan dokumentasi.

\section{Hasil Penelitian dan Pembahasan Implementasi Pembelajaran Berbasis Karakter Pada Pelaksanaan Pembelajaran Bahasa Indonesia di Kelas VIII}

Hasil analisis peneliti menunjukkan bahwa dalam (APKG 1) termuat perencanaan pembelajaran yang terdiri dari RPP dan silabus guru memiliki beberapa aspek penilaian yang terdiri dari: penilaian proses perumusan indikator dan tujuan pembelajaran, pemilihan dan pengorganisasian materi, pemilihan sumber dan media pembelajaran, dan skenario/langkah kegiatan. Menunjukkan bahwa aspek yang dinilai adalah 18,87\% yaitu masih kurang.

Hasil analisis peneliti menunjukkan bahwa dalam (APKG 2) termuat pelaksanaan pembelajaran dan evaluasi pembelajaran memiliki beberapa aspek penilaian yang terdiri dari: pra pembelajaran, pembukaan pembelajaran, kegiatan inti, penguasaan materi pembelajaran, pendekatan/strategis pembelajaran, pemanfaat media/sumber belajar, pembelajaran yang memicu dan memelihara ketertiban siswa, penilaian proses dan hasil belajar, penggunaan bahasa, penutup, dan kemampuan menilai proses. Menunjukkan bahwa aspek yang dinilai adalah $84 \%$ yaitu baik.

Faktor Penghambat dalam Implementasi Pelmbelajaran Berbasis Karakter Pada Mata Pelajaran Bahasa Indonesia Siswa Kelas VIII SMP Negeri Satu Atap 1 Marobo Kab. Muna

41 | $\mathrm{P}$ a g e 
Ada beberapa faktor yang menjadi penghambat dalam faktor luar yang terdiri dari 1) lingkungan, dan 2) pemerintah yaitu:

\section{Faktor Lingkungan}

Faktor lingkungan terbagi atas tiga yaitu faktor lingkungan keluarga, faktor lingkungan sekolah, dan faktor teman sebaya. Dapat diuraiakan sebagai berikut:

a) Faktor lingkungan keluarga Faktor penghambat dalam mengimplementasikan pembelajaran berbasis karakter pada mata pelajaran Bahasa Indonesia siswa kelas VIII SMP Negeri satu atap 1 Marobo Kab. Muna, guru Bahasa Indonesia mengatakan bahwa:

"Keluarga bisa menjadi faktor penghambat dalam mengimplementasikan pembelajaran berbasis karakter pada mata pelajaran Bahasa Indonesia, saat guru disekolah menerapkan nilai karakter dalam pembelajaranya tetapi ketika siswa pulang di rumahnya orang tua lah yang sangat berperan membentuk karakter tersebut. Tetapi dikarenakan kesibukan dan kurang perhatianya orang tua terhadap siswa mereka kebanyakan menyerahkan hak sepenuhnya kepada sekolah...." (hasil wawancara dengan guru, pada tanggal 16 Desember 2019).

Dari pernyataan di atas dapat disimpulkan bahwa dalam mengimplementasikan pembelajaran berbasis karakter pada mata pelajaran Bahasa Indonesia perlu di dukung oleh keluarga yang memahami arti pentingnya pendidikan karakter, sehingga bisa membantu guru dalam mewujudkan nilai karakter yang diterapkan.

b) Faktor lingkungan sekolah

Faktor lingkungan sekolah juga bisa menjadi penghambat dalam mengimplementasikan pembelajaran berbasis karakter pada mata pelajaran
Bahasa Indonesia siswa kelas VIII SMP Negeri satu atap 1 Marobo Kab. Muna, guru Bahasa Indonesia mengatakan bahwa:

"Semua yang ada di lingkungan sekolah baik kepala sekolah, guru, tata usaha wajib memberikan contoh dan teladan yang baik terkait penerapan pendidikan karakter, pada umumnya siswa meniru perilaku dari gurunya, yang menjadi penghambat dalam mengimplementasikan pelajaran Bahasa Indonesia berbasis karakter juga adalah kurangnya pelatihan yang dijalani oleh guru terkait pelajaran Bahasa Indonesia berbasis karakter, saya menjalani pelatihan terkait pendidikan karakter baru satu kali" (hasil wawancara dengan guru, pada tanggal 16 Desember 2019).

Dari pernyataan di atas dapat disimpulkan bahwa dalam mengimplementasikan pembelajaran berbasis karakter pada mata pelajaran Bahasa Indonesia sudah menjadi tugas dari guru, disamping guru memberikan ilmu pengetahuan juga menanamkan nilai karakter kepada peserta didiknya dengan memberikan tingkah laku yang patut ditiru. Guru juga masih perlu mengikuti banyak pelatihan terkait pembeajaran Bahasa Indonesia berbasis karakter. Guru berperan dalam pemberian pelayanan untuk memudahkan siswa dalam kegiatan proses pembelajaran.

c) Faktor teman sebaya

Faktor teman sebaya merupakan salah satu penghambat dalam mengimplementasikan pembelajaran berbasis karakter pada mata pelajaran Bahasa Indonesia siswa kelas VIII SMP Negeri satu atap 1 Marobo Kab. Muna, guru Bahasa Indonesia mengatakan bahwa:

"Teman sepergaulan mempunyai pengaruh yang cukup besar untuk membuat anak menjadi baik, dan juga membuat anak yang 
suka melanggar norma-norma yang berlaku di masyarakat. Biarpun guru telah menanamkan pendidikan karakter dalam pembelajaranya tetapi ketika diluar lingkungan sekolah, faktor teman sepergaulan yang membentuk karakter peserta didik tersebut" (hasil wawancara dengan guru, pada tanggal 16 Desember 2019).

Dari pernyataan di atas dapat disimpulkan bahwa dalam mengimplementasikan pembelajaran berbasis karakter pada mata pelajaran Bahasa Indonesia perlu adanya dukungan dari teman sebayanya. Teman-teman yang memiliki akhlak yang baik lebih cepat membentuk karakter peserta didik yang baik. Interaksi teman sebaya dalam kelompok mempunyai pengaruh dominan dalam membentuk karakter siswa. Masa perkembangan siswa yang masih sangat dipengaruhi teman sebaya diharapkan mampu memilih teman yang bisa membawa kearah pergaulan yang baik sehingga akan mempengaruhi pembentukan karakter yang baik. Persahabatan dengan teman sebaya dan kelompok sangat penting untuk saling memotivasi dan memberikan keteladanan yang baik sehingga mampu memberikan karakter yang baik dalam persahabatan.

\section{Faktor Pemerintah}

Kurikulum yang saat ini dijalani oleh pemerintah adalah kurikulum 13 (K13) yang berkarakter, dimana nilai-nilai karakter diselipkan pada pembelajaran guru yang termuat dalam RPP dan silabus guru. Hal ini diungkapkan oleh guru Bahasa Indonesia yang mengatakan bahwa:

"Salah satu faktor penghambat dalam mengimplementasikan pembelajaran berbasis karakter pada mata pelajaran Bahasa Indonesia adalah kami guru masih menitik beratkan pada kemampuan kognitif. Orientasi pembelajaran masih banyak dipengaruhi oleh nilai rapor bukan internalisasi karakter itu sendiri" (hasil wawancara dengan guru, pada tanggal 16 Desember 2019).

Dari pernyataan di atas dapat disimpulkan bahwa dalam mengimplementasikan pembelajaran berbasis karakter pada mata pelajaran Bahasa Indonesia guru perlu menyeimbangkan antara kognitif dan karakter siswa. Adanya interaksi antara guru dengan siswa dapat menimbulkan karakter siswa menjadi terbentuk, terlebih dengan adanya beberapa faktor pembelajaran dan lingkungan. Pembentukan karakter siswa dalam Kurikulum 2013 terlihat dari usaha-usaha guru dalam kegiatan pembelajaran, mulai dari perencanaan, pelaksanaan, dan penilaian pembelajaran.

\section{B. Faktor Dalam}

Faktor dalam diri siswa merupakan salah satu penghambat dalam mengimplementasikan pembelajaran berbasis karakter pada mata pelajaran Bahasa Indonesia siswa kelas VIII SMP Negeri satu atap 1 Marobo Kab. Muna, guru Bahasa Indonesia mengatakan bahwa:

"Salah satu faktor penghambat dalam mengimplementasikan pembelajaran berbasis karakter pada mata pelajaran Bahasa Indonesia adalah faktor dalam diri siswa seperti mental, kesadaran, motivasi dan disiplin. Belum adanya mental siswa dalam mempresentasikan hasil belajarnya, siswa juga belum sepenuhnya memahami pentingnya nilai kejujuran, motivasi belajar siswa hanya pada saat siswa berada di sekolah, dan disiplin siswa yang masih banyak melanggar aturan yang ditetapkan di 
sekolah" (hasil wawancara dengan guru, pada tanggal 16 Desember 2019).

Dari pernyataan di atas dapat disimpulkan bahwa dalam mengimplementasikan pembelajaran berbasis karakter pada mata pelajaran Bahasa Indonesia, perlu adanya pendekatan diri yang dilakukan guru terhadap siswa, agar mengetahui masalah apa yang ada di dalam dirinya saat karakter yang ditunjukkan kurang baik. Guru bisa menjadi teman, guru, dan orang tua bagi siswa. Pada penerapanya nilai pendidikan karakter masih sulit dilaksanakan oleh siswa. Pelanggaran terhadap tata tertib sekolah tidak dapat dipisahkan dengan siswa-siswi. Terkadang dalam diri mereka terbesit untuk melakukan pelanggaranpelanggaran baik dengan tujuan ataupun tanpa tujuan.

Faktor Penghambat dalam Implementasi Pelmbelajaran Berbasis Karakter Pada Mata Pelajaran Bahasa Indonesia Siswa Kelas VIII SMP Negeri Satu Atap 1 Marobo Kab. Muna 1. Faktor Fisiologis

Faktor fisiologis merupakan salah satu faktor pendukung dalam mengimplementasikan pembelajaran berbasis karakter pada mata pelajaran Bahasa Indonesia siswa kelas VIII SMP Negeri satu atap 1 Marobo Kab. Muna, guru Bahasa Indonesia mengatakan bahwa:

"Siswa yang ada di kelas VIII rata-rata memiliki kondisi fisik yang sehat dan bugar sehingga sangat membantu aktivitas proses pembelajaran mereka, contoh absen yang menunjukkan kehadiran $90 \%$. Selain itu fisik faktor kecerdasan awal yang dimiliki oleh siswa juga berpengaruh dalam proses pelajaran Bahasa Indonesia berbasis karakter, anak yang aktif cenderung memiliki nilai teratas semenjak dari kelas sebelumnya" (hasil wawancara dengan guru, pada tanggal 16 Desember 2019).

Dari pernyataan di atas dapat
disimpulkan bahwa dalam
mengimplementasikan pembelajaran berbasis karakter pada mata pelajaran Bahasa Indonesia siswa kelas VIII SMP Negeri Satu Atap 1 Marobo, kondisi fisik siswa yang sehat dan kecerdasan awal yang dimiliki oleh siswa menjadi faktor pendukung dalam pelajaran Bahasa Indonesia berbasis karakter. keadaan fungsi jasmani sangat mempengaruhi aktifitas belajar siswa, di dalam tubuh yang sehat terdapat jiwa yang sehat. Pembentukan kepribadian karakter juga berhubungan langsung dengan kondisi fisik seseorang. Dari hasil observasi yang dilakukan peneliti diketahui bahwa ratarata kelas VIII menunjukkan kehadiran yang sangat baik yaitu $95 \%$.

\section{Faktor lingkungan non sosial}

Faktor lingkungan non sosial merupakan salah satu faktor pendukung dalam mengimplementasikan pembelajaran berbasis karakter pada mata pelajaran Bahasa Indonesia siswa kelas VIII SMP Negeri satu atap 1 Marobo Kab. Muna, guru Bahasa Indonesia mengatakan bahwa:

"lingkungan non sosial juga merupakan faktor pendukung dalam mengimplementasikan pembelajaran berbasis karakter pada mata pelajaran Bahasa Indonesia, lingkungan alamiah yang segar, tidak panas, tidak dingin, sinar matahari tidak terlalu silau, tidak terlalu gelap dan tenang. Faktor tersebut merupakan salah satu penentu kenyamanan belajar siswa dalam proses pembelajaran berlangsung. Sekolah yang 
membuat nyaman bisa membentuk kepribadian dan karakter yang baik kepada siswa, rasa nyaman ketika berada disekolah, keakbraban yang dimiliki oleh guru dan siswa. Fasilitas sekolah seperti mushola juga membuat siswa lebih dekat kepada sang pencipta sehingga mengajarkan sejak dini artinya sebuah keimanan dan ketakqwaan kepada peserta didik" (hasil wawancara dengan guru, pada tanggal 16 Desember 2019).

Dari pernyataan di atas dapat disimpulkan bahwa lingkungan yang alami di sekolah dan adanya sarana prasarana seperti mushola menjadi faktor pendukung mengimplementasikan pembelajaran berbasis karakter pada mata pelajaran Bahasa Indonesia siswa kelas VIII SMP Negeri satu Atap 1 Marobo.

Adapun nilai karakter yang terkait erat Tuhan Yang Mahakuasa adalah nilai religius. Hal yang semestinya dikembangkan dalam diri anak didik adalah terbangunya pikiran, perkataan, dan tindakan anak didik yang diupayakan senantiasa berdasarkan nilai-nilai ketuhanan atau yang bersumber dari ajaran agama yang dianut oleh seseorang benarbenar dipahami dan diamalkan dalam kehidupan sehari-hari. Tersedianya sarana dan prasana seperti musholah membantu peserta didik untuk tetap beribadah dimana dan kapanpun. Sholat dhuzur biasa dilaksanakan pada pukul 11.30, adanya waktu untuk ISHOMA membuat kegiatan yang bermanfaat dan membentuk karakter peserta didik selama berada disekolah.

\section{Penutup}

Berdasarkan hasil penelitian dan pembahasan dapat disimpulkan bahwa: Berdasarkan hasil penelitian dan pembahasan dapat disimpulkan bahwa: 1. Implementasi pembelajaran berbasis karakter pada mata pelajaran Bahasa
Indonesia siswa kelas VIII SMP Negeri Satu Atap 1 Marobo dalam hasil analisis (APKG 1) menunjukkan aspek yang dinilai masih kurang yaitu 18,87\%, dan (APKG 2) menunjukkan aspek yang dinilai sudah baik yaitu $84 \%$. Dalam pelaksanaanya terdapat kegiatan-kegiatan guru yang belum sepenuhnya ditanamkan, seperti: 1) guru masih tidak tepat waktu, (waktu pembelajaran telah berlangsung, guru baru masuk setelah beberapa menit kemudian). Hal ini menunjukkan bahwa guru tersebut masih kurang dalam hal disiplin waktu, dan 2) pada pemanfaatan media guru hanya menggunakan media sendiri dan hanya menjelaskan kepada siswa tanpa melibatkan mereka dalam pemanfaatan media, sehingga memaksa siswa untuk berkhayal tentang materi yang sedang diajarkan.

2. Terdapat beberapa faktor penghambat dalam implementasi pembelajaran berbasis karakter pada mata pelajaran Bahasa Indonesia siswa kelas VIII SMP Negeri Satu Atap 1 Marobo yaitu: faktor luar dan faktor dalam, faktor luar terdiri dari faktor lingkungan dan pemerintah, sedangkan pada faktor dalam yaitu mental, kesadaran, motivasi dan disiplin.

Terdapat beberapa faktor pendukung dalam implementasi pembelajaran berbasis karakter pada mata pelajaran Bahasa Indonesia siswa kelas VIII SMP Negeri Satu Atap 1 Marobo yaitu: faktor eksternal dan faktor internal, faktor internal dapat dilihat dari fisiologis siswa, sedangkan pada faktor eksternal dapat dilihat dari lingkungan non sosial. 
Daftar Pustaka

Abidin.Yunus.2013.Desain Sistematis Pembelajaran Dalam Konteks Kurikulum.Bandung: PTRefika Aditama.

Aqib, Zainal, dkk. 2011. Panduan dan Aplikasi Pendidikan Karakter. Bandung: Yrama Widya.

Ardan, Fatmawati. 2017. Implementasi Pendidikan Karakter Dalam Proses Pembelajaran Matematika Pada Kelas VIII SMP Negeri 2 Sungguminasa.http://repositori.uin $=$ alauddin.ac.id/6549/1/SKRIPSI\% 20FATMAWATY\%20ARDAN O pt.pdf. Diunduh pada hari senin, tanggal 23 september, pukul 08.:00 Wita

Badara, dkk. 2018. CULTURAL ENGINEERING IN TEACHING AND LEARNING: A Study in Kendari as a Multietchnic City in Indonesia. (DOI http://www.wseas.us/elibrary/conferences/2015/Salerno/E DU/EDU-28.pdf)

Daryanto, dkk. 2013. Implementasi Pendidikan Karakter Di sekolah. Yogyakarta: Gava Media.

Faridah, Alawiyah. 2012. Kebijakan Dan Pengembangan Pembangunan Karakter Melalui Pendidikan di Indonesia. jurnal.dpr.go.id/index.php/aspirasi /article/view/259/200. Diunduh pada hari sabtu, tanggal 11 September, pukul 09:00 Wita.

Ibeng.Parta.https://pendidikan.co.id/peng ertian-implementasi-tujuancontoh-dan-menurut-paraahli/Diunduh pada hari selasa, tanggal 27 Agustus, pukul 19:58 Wita.

Muthohar, Ahmad. 2015. Model Pengembangan Pendidikan
Karakter Studi Pada Sekolah Menengah Pertama (SMP) di Samarinda.

https://academia.edu.Artikel EJournal, 2-3 Di unduh pada hari senin, tanggal 16 september, pukul 09:00 Wita.

Sahlan, Asmaun, dkk. 2014. Desain Pembelajaran Berbasis Pendidikan Karakter. Jogjakarta:Ar-Ruzz Media.

Setiawan.Ebta.2019. https://kbbi.web.id/implementasi. Badan Pengembangan dan PembinaanBahasa.Kemendikbud (pusat bahasa).Diunduh pada hari senin, tanggal 2 Septemer2019, pukul 09:00 Wita.

46 | P a g e 